\title{
Biliary Tract Complications after Liver Transplantation: A Review
}

\author{
Maciej Wojcicki ${ }^{a}$ Piotr Milkiewicz ${ }^{\mathrm{a}}$ b Michael Silva $^{\mathrm{c}}$ \\ a Division of Hepatobiliary Surgery and Liver Transplantation, Department of General and Transplant Surgery, \\ M. Curie Hospital, and ${ }^{b}$ Liver Unit, Department of Gastroenterology, Pomeranian Medical University, Szczecin, Poland; \\ 'Liver and Hepatobiliary Unit, Queen Elizabeth Hospital, University Hospital Birmingham, NHS Foundation \\ Trust, Birmingham, UK
}

\section{Key Words}

Duct-to-duct anastomosis • Hepaticojejunostomy • Biliary

leak $\cdot$ Biliary stricture $\cdot$ Ischemic-type biliary lesions

\begin{abstract}
Biliary complications continue to be a major cause of morbidity in liver transplant recipients with an incidence of 10 $30 \%$ following whole-organ transplantation and a mortality rate of up to $10 \%$. Biliary leaks and strictures are most common but sphincter of Oddi dysfunction, hemobilia, and biliary obstruction are also observed. Biliary complications may be related to various factors such as hepatic artery patency, preservation injury, cytomegalovirus infection, chronic ductopenic rejection, $\mathrm{ABO}$ incompatibility, and technical reasons. The latter include imperfect anastomosis, T-tube-related complications and the use of partial liver grafts when cut surface biliary leaks or inadvertent bile duct injuries may occur during parenchymal division. The usage of a T-tube for duct-to-duct anastomosis in whole-organ liver transplantation remains controversial, mainly because of the high rates of T-tube-related complications observed in many series. In this article we review the etiology, as well as the main types of biliary complications according to the technique of biliary reconstruction and liver transplant procedure performed. Their management is also discussed with interventional radiology and endoscopic techniques emerging as the preferred treatment option, obviating the need for surgery in a selected majority of patients.

Copyright $\odot 2008$ S. Karger AG, Basel
\end{abstract}

\section{Introduction}

Biliary complications, once considered as the technical 'Achilles heel' of orthotopic liver transplantation (OLT) [1-3], still remain a common source of morbidity and mortality. In early reports by Starzl et al. [2] and Calne et al. [4], they resulted in morbidity rates of 34$50 \%$ and mortality of $25-30 \%$. With improvements in organ selection, retrieval, preservation, and implantation techniques such complications have been reduced dramatically. Biliary complications, however, still occur in $10-30 \%$ following whole-organ OLT resulting in mortality rates up to $10 \%$ of cases [5-11] (table 1).

Biliary leaks and strictures are the most common biliary complications, but sphincter of Oddi dysfunction, hemobilia, and biliary obstruction from cystic duct mucocele, stones, sludge or casts have also been observed [5, $12,13]$. The risk of specific biliary complications is related to the technique of biliary reconstruction, use of a biliary drain following duct-to-duct anastomosis, and the type of a liver transplant procedure performed. Reduced size, split-liver transplantation and living-donor liver transplantation are associated with an increased risk of these complications with a reported incidence of 10 $60 \%$ [14-25]. This may be as a result of devascularization of the bile duct at the hilar dissection, failure to recognize anomalies of the biliary tree, technically challenging biliary reconstruction (small-size ducts, multiple ducts), and biliary leaks from the cut edge.

\section{KARGER}

Fax +4161306 1234 E-Mail karger@karger.ch www.karger.com
(C) 2008 S. Karger AG, Basel

0253-4886/08/0254-0245\$24.50/0

Accessible online at:

www.karger.com/dsu
Maciej Wojcicki, MD

Division of Hepatobiliary Surgery and Liver Transplantation

M. Curie Hospital, ul. Arkonska 4

PL-71-455 Szczecin (Poland)

Tel./Fax +4891 45416 93, E-Mail drmwojcicki@wp.pl 
Table 1. Biliary complications after cadaveric whole-organ OLT with duct-to-duct anastomosis and Roux-en-Y hepaticojejunostomy

\begin{tabular}{|c|c|c|c|c|c|c|}
\hline Reference & Center & Year & $\mathrm{n}$ & Total, $\%$ & Leaks, \% & $\begin{array}{l}\text { Strictures and } \\
\text { obstructions, \% }\end{array}$ \\
\hline Greif et al. [5] ${ }^{1}$ & Pittsburgh & 1994 & 1,792 & 12 & 3 & 5 \\
\hline Verran et al. [6] ${ }^{1}$ & Ontario & 1997 & 502 & 14 & 2 & 7 \\
\hline \multicolumn{7}{|c|}{ Duct-to-duct anastomosis } \\
\hline Lebeau et al. [119] & Pittsburgh & 1990 & 193 & 20 & 2 & 18 \\
\hline Belli et al. [120] & Milan & 1991 & 100 & 4 & 2 & 2 \\
\hline Neuhaus et al. [7] & Berlin & 1994 & 300 & 9 & 0.3 & 4 \\
\hline O'Connor et al. [8] & Boston & 1995 & 147 & 33 & 22 & 12 \\
\hline Rabkin et al. [9] & Portland & 1998 & 227 & 30 & 19 & 12 \\
\hline Davidson et al. [10] & Royal Free & 1999 & 100 & 31 & 17 & 14 \\
\hline \multicolumn{7}{|c|}{ Roux-en-Y hepaticojejunostomy } \\
\hline Ringe et al. [26] & Hannover & 1989 & 84 & 24 & 12 & 2 \\
\hline Rouch et al. [86] & Chicago & 1990 & 72 & 21 & 13 & 6 \\
\hline Lebeau et al. [119] & Pittsburgh & 1990 & 187 & 12 & 9 & 3 \\
\hline
\end{tabular}

The percentages are based on the total number of cases.

${ }^{1}$ Both duct-to-duct anastomoses and Roux-en-Y hepaticojejunostomies included.

\section{Biliary Reconstruction at Liver Transplantation}

Biliary reconstruction is the final step of OLT which is done after all the vascular anastomoses have been completed. An end-to-end duct-to-duct anastomosis is the procedure of choice in most institutions following wholeorgan OLT in patients with healthy native bile ducts of suitable caliber $[5,6]$. This technique yields a physiological bilioenteric continuity and allows biliary complications to be treated endoscopically. A side-to-side variant of duct-to-duct anastomosis has also been used by some groups and good results have been obtained $[7,26]$. The gallbladder conduit technique used in the early years utilized the gallbladder as a pedicle graft conduit between the donor and recipient bile ducts [1]. It has largely been abandoned because of the associated bile stasis with stone formation and frequent episodes of cholangitis which lead to the inferior outcome $[27,28]$.

Roux-en-Y hepaticojejunostomy is utilized in cases of preexisting biliary tract disease (sclerosing cholangitis, biliary atresia), large disparity in size or small caliber ducts, and may be preferred in case of retransplantations because of inadequate recipient duct length $[29,30]$. In the early years of living-donor liver transplantation and split liver transplantation, Roux-en-Y hepaticojejunostomy was the standard biliary reconstructive technique. With growing experience of surgical technique and more emphasis placed on preserving the blood supply around the native common bile duct [31, 32], duct-to-duct anastomosis with or without a biliary drain has been increasingly reported in right lobe living-donor transplants [33-38], as well as in right lobe split transplants [39-45]. Initially, duct-to-duct anastomosis in right lobe living-donor transplants was only performed when a single donor duct was available, whereas more recently, the use of the recipient right and left hepatic ducts, as well as the cystic duct has been reported when multiple anastomoses are needed [46-48]. Alternatively, both duct-to-duct and bilioenteric reconstructions may also be used in the same patient. Hepaticojejunostomy remains the method of choice for biliary reconstruction in the left lateral segment split liver grafts, as well as in a left lateral segment or left lobe living-donor grafts [39, 41-43, 49, 50]. However, duct-toduct anastomosis in left lobe living-donor liver transplants has also been shown to be feasible $[51,52]$.

\section{Classification and Etiology of Biliary Complications}

Biliary complications appear attributable to various factors, including hepatic artery thrombosis or stenosis, technical reasons, as well as ischemia-reperfusion injury and immunological injury, which may lead to the ischemic-type biliary lesions [53-61]. The classification of biliary complications should mainly refer to the etiology which appears most relevant for data analysis and its fur- 
ther interpretation. In this respect, biliary strictures should be clearly distinguished from bile duct obstructions, which may be intrinsic or due to extrinsic compression of the biliary tree [62] (table 2). In this article we propose to classify biliary complications according to the criteria of their etiology and frequency after OLT (table 3).

Technical reasons for biliary complications include imperfect anastomosis leading to a leak and/or stricture, T-tube-related complications and the use of partial liver grafts when cut surface biliary leaks or inadvertent bile duct injuries may occur during parenchymal division. With ex vivo splits, biliary complication rates of $15-40 \%$ in the early years $[15-17,19,20]$, and $9-26 \%$ in more recent series $[40,41,45,49]$ have been reported. A new technique of in situ liver splitting has been developed and has reduced biliary complication rates in partial graft transplantation [39, 63]. However, the incidence of complications following in situ liver splitting varies from 0 to $41 \%$, which may reflect center experience and its volume as a predominant factor (table 4) [39, 42-44, 63-65]. The excellent results from in situ splits come from centers with large experience in liver transplantation and previous experience with ex situ splitting [39, 42].

Ischemic-type biliary lesions appear to be a broad pathological entity characterized by intrahepatic strictures and dilatations seen on cholangiogram, which by definition occur in the absence of hepatic artery thrombosis or stenosis [54]. The pathogenesis of ischemic-type biliary lesions remains unclear; however, an increased frequency of such lesions in patients with prolonged cold ischemia time [54, 66-69], delayed rearterialization of the graft [70] or transplants from non-heart-beating donors [71] suggests ischemia-reperfusion injury as a causative factor. Immunologically related ischemic-type biliary lesions comprise injury to the biliary epithelium and/or vascular endothelium in the course of chronic rejection, cytomegaloviral infection, recurrent sclerosing cholangitis and $\mathrm{ABO}$ incompatible transplantation [5461]. It has also been suggested that bile salts within the biliary tree can be cytotoxic to the ductal epithelium of allografts with long preservation times, resulting in intrahepatic stricture formation [54]. For this reason most surgeons routinely flush the donor biliary tree to remove stagnant bile at the time of organ procurement in order to prevent direct chemical injury of the biliary epithelium by bile during cold storage. Pressurized aortic perfusion as well as the use of low viscosity preservation solutions have also been proposed as additional important measures that may limit the incidence of biliary strictures in the liver transplant setting [72-74].
Table 2. Etiology of bile duct obstruction after liver transplantation

Intrinisic

Biliary sludge, cast, or stones

T-tube obstruction

T-tube/stent remnants

Thrombus in hemobilia

Nematodes

Extrinisic

Biloma/hematoma/abscess

False aneurysm

Cystic duct mucocele

Recurrent/de novo cancer

Post-transplant lymphoproliferative disease

Table 3. Classification of biliary complications after liver transplantation

I Ischemic biliary complications due to hepatic artery throm-

bosis or stenosis

Stricture

Leak

Bile collection (biloma)

Biliary abscess

II Technical biliary complications

Anastomotic stricture

Anastomotic leak

T-tube related

Cut surface leak ${ }^{1}$

Missed segmental duct leak ${ }^{1}$

Kinking

Cystic duct mucocele

III Ischemic-type biliary lesions

Ischemia-reperfusion injury related

Immunological $^{2}$

Idiopathic

IV Infectious biliary complications/cholangitis

V Uncommon biliary complications Sphincter of Oddi dysfunction

Biliary stones, sludge, and casts

Hemobilia

Roux limb stasis or torsion

Roux limb bleeding or perforation

Post-transplantation lymphoproliferative disease

Recurrent/de novo cancer

${ }^{1}$ Partial liver grafts.

${ }^{2}$ Strictures related to chronic rejection, ABO incompatibility, recurrent primary sclerosing cholangitis or cytomegalovirus-induced ductopenia. 
Table 4. Biliary complications after split-liver transplantation

\begin{tabular}{|c|c|c|c|c|c|c|c|}
\hline Reference & Center & Year & $\mathrm{n}$ & Total, \% & Leaks, \% & $\begin{array}{l}\text { Cut-edge } \\
\text { leaks, \% }\end{array}$ & $\begin{array}{l}\text { Strictures } \\
\%\end{array}$ \\
\hline \multicolumn{8}{|c|}{ Left lateral segment split-liver grafts } \\
\hline Rogiers et al. [39] ${ }^{1}$ & Hamburg & 1996 & 7 & 0 & 0 & 0 & 0 \\
\hline Rela et al. [41] & King's & 1998 & 22 & 14 & 9 & 5 & 0 \\
\hline Yersiz et al. $[42]^{1}$ & Los Angeles & 2003 & 94 & 9 & 7 & 7 & 1 \\
\hline Renz et al. $[43]^{2}$ & US & 2004 & 207 & $13^{3}$ & 10 & 9 & 3 \\
\hline \multicolumn{8}{|l|}{ Right lobe split-liver grafts } \\
\hline Rogiers et al. $[39]^{1}$ & Hamburg & 1996 & 7 & 0 & 0 & 0 & 0 \\
\hline Azoulay et al. [40] & Villejuif & 1996 & 21 & 19 & 11 & 4 & 7 \\
\hline Rela et al. [41] & King's & 1998 & 22 & 14 & 14 & 14 & 5 \\
\hline Yersiz et al. $[42]^{1}$ & Los Angeles & 2003 & 71 & 10 & 7 & 4 & 3 \\
\hline Renz et al. $[43]^{2}$ & US & 2004 & 152 & $11^{4}$ & 9 & 9 & 2 \\
\hline Sampietro et al. $[24]^{2}$ & Brussels & 2005 & 36 & 35 & 20 & 11 & 26 \\
\hline Spada et al. [44] ${ }^{1}$ & Palermo & 2005 & 15 & 27 & - & - & - \\
\hline Wojcicki et al. [45] & Birmingham & 2006 & 70 & 26 & 21 & 11 & 4 \\
\hline Corno et al. $[65]^{1}$ & Bergamo & 2006 & 22 & 41 & - & - & - \\
\hline
\end{tabular}

The percentages are based on the total number of cases.

${ }^{1}$ In situ splits. ${ }^{2}$ Both in situ and ex vivo splits included. ${ }^{3} 12 \%$ for in situ and $15 \%$ for ex vivo splits. ${ }^{4} 17 \%$ for in situ and $5 \%$ for ex vivo splits.

Cholestasis in a liver transplant patient may also be caused or aggravated by biliary sludge formation [75-78]. Biliary sludge consists of inspissated and thickened bile and/or connective tissue originating from destroyed bile duct walls. It may lead to a serious biliary obstruction due to a cast formation and life-threatening cholangitis. Biliary casts are more likely to develop in the setting of liver graft ischemia, biliary strictures, ischemic-type biliary lesions, and when stagnant bile in the donor biliary tree had not been flushed out prior to cold storage.

\section{Clinical Presentation and Diagnosis}

The majority of biliary complications are diagnosed within 6 months after OLT with an estimated one third occurring within 1 month and two thirds within 3 months of surgery [5]. Most of them are biliary strictures which present commonly with cholestasis and associated abnormalities in liver function tests, with pyrexia or septicemia in the presence of coexistent cholangitis. Clinical features are often nonspecific and may be masked by steroid and immunosuppressive therapy. They may include abdominal discomfort or the absence of peritoneal signs even in the case of diffuse biliary peritonitis due to a biliary leak in the immediate postoperative period. For this reason, any clinical deterioration of the patient in the early postoperative period including pain, fever, prolonged ileus or ascites and/or liver allograft dysfunction necessitates algorithmic use of diagnostic modalities in order to make a proper diagnosis and start treatment promptly [12]. Doppler ultrasonography is the first-line investigation of choice because of the frequent association of biliary complications with the presence of hepatic artery thrombosis or stenosis $[5,53]$. Abnormal or absent signals are further investigated by conventional visceral angiography [12], or more recently by noninvasive computed tomography (or magnetic resonance) angiography $[79,80]$. Cholestasis early after OLT can be caused by many pathologic conditions like acute cellular rejection, vascular thrombosis, preservation injury, ascending cholangitis, drug toxicity, hemolysis, recurrent hepatitis, steatosis from parenteral nutrition, and generalized sepsis [12, 81]. This underscores the need for a multidisciplinary approach to the care of liver transplant recipients, and histopathological expertise is required. While rejection is the most common cause of liver allograft dysfunction within the first 2-4 weeks after transplantation, biliary complications predominate as the leading cause of abnormal liver function more than 3 months after OLT and occur in up to $15 \%$ of cases [82]. Ultrasound evaluation of the biliary tree is of limited value because bile duct 
Table 5. Incidence of biliary complications after liver transplantation with duct-to-duct anastomosis with (T-tube) and without a T-tube (non-T-tube)

\begin{tabular}{|c|c|c|c|c|c|c|}
\hline \multirow[t]{2}{*}{ Reference } & \multicolumn{2}{|l|}{ Total } & \multicolumn{2}{|l|}{ Strictures } & \multicolumn{2}{|l|}{ Leaks } \\
\hline & T-tube & non-T-tube & T-tube & non-T-tube & T-tube & non-T-tube \\
\hline Rouch et al. [86] & $9 / 25(36 \%)$ & $7 / 38(18 \%)$ & - & - & $5 / 25(20 \%)$ & $1 / 38(3 \%)$ \\
\hline Rolles et al. [87] & $4 / 16(25 \%)$ & $20 / 90(22 \%)$ & 0 & $10 / 90(11 \%)$ & $4 / 16(25 \%)$ & $10 / 90(11 \%)$ \\
\hline Randall et al. [93] & $13 / 59(22 \%)^{b}$ & $7 / 51(14 \%)$ & $8 / 59(14 \%)$ & $7 / 51(14 \%)$ & $5 / 59(8 \%)^{d}$ & 0 \\
\hline Vougas et al. [88] $^{1}$ & $5 / 30(17 \%)$ & $6 / 30(20 \%)$ & $2 / 30(7 \%)$ & $6 / 30(20 \%)$ & $1 / 30(3 \%)$ & 0 \\
\hline Nuno et al. $[89]^{1}$ & $5 / 50(10 \%)^{\mathrm{c}}$ & $16 / 48(33 \%)$ & $1 / 50(2 \%)$ & $6 / 48(13 \%)$ & $3 / 50(6 \%)$ & $8 / 48(17 \%)$ \\
\hline Rabkin et al. [9] & $43 / 124(35 \%)$ & $11 / 44(25 \%)$ & $7 / 124(6 \%)^{\mathrm{a}}$ & $10 / 44(23 \%)$ & $36 / 124(29 \%)$ & $1 / 44(2 \%)$ \\
\hline Scatton et al. $[90]^{1}$ & $30 / 90(33 \%)^{d}$ & $14 / 90(15 \%)$ & $3 / 90(3 \%)$ & $6 / 90(7 \%)$ & $9 / 90(10 \%)$ & $2 / 90(2 \%)$ \\
\hline
\end{tabular}

${ }^{\mathrm{a}} \mathrm{p}<0.05 ;{ }^{\mathrm{b}} \mathrm{p}=0.01 ;{ }^{\mathrm{c}} \mathrm{p}<0.01 ;{ }^{\mathrm{d}} \mathrm{p}<0.005$

1 Prospective randomized trials.

dilatation may be absent in the presence of biliary obstruction in liver transplant patients [83]. The indication for endoscopic retrograde cholangiopancreatography or percutaneous transhepatic cholangiography must therefore often be based on the clinical presentation and histologic findings of biliary obstruction and/or chronic cholangitis in liver biopsy [12]. Magnetic resonance cholangiography is a noninvasive and very promising diagnostic modality that can detect pathologic biliary tract changes and provide information for planning invasive therapeutic procedures [84].

\section{Use of T-Tube and Biliary Complications}

There is ongoing discussion regarding the use of a Ttube for duct-to-duct anastomosis in whole-organ liver transplantation. A T-tube drainage at OLT has traditionally been used to provide easy access to the biliary tree and lower the pressure in the biliary system, which may be elevated in the case of stenosis at the anastomotic site or due to sphincter of Oddi dysfunction $[7,9,85]$. Additionally it aids monitoring of the quality and output of bile and may reduce the incidence of late anastomotic biliary strictures $[9,86-90]$ (table 5) and the need for their surgical repair $[9,89,91]$. Biliary drains, however, may increase complication rates by frequently observed leaks following bile drain removal, its dislodgement, cholangitis and biliary obstruction $[5,8,90,92,93]$. The incidence of biliary drain-related biliary complications range between 10 and 22\%, with bile leak after bile drain removal occurring in $5-15 \%$ of patients $[82,90,94-96]$. This is due to inadequate development of a fibrous fistulous tract along the course of the drain as a result of impaired fibrogenesis under immunosuppression with the use of steroids [97]. Several measures have been proposed to reduce the incidence of biliary leaks following bile drain removal. These include the use of rubber tubes instead of silicone ones [7], leaving a counter drain or the T-tube in the tract under fluoroscopic guidance $[98,99]$, or delayed removal of biliary drains until 4-6 months after OLT $[100,101]$. Transcystic or internal endobiliary stents, as well as routine interventional radiologic procedures have also been proposed to overcome these problems $[11,100$, 102-104]. Many groups have abandoned the use of a Ttube at whole-organ OLT, which has been shown to be safe, efficacious, and cost-effective, as compared to biliary reconstruction over a T-tube $[86,87,105,106]$. This practice conforms with the results from two prospective, randomized trials showing no advantage of biliary drainage at whole-organ OLT [88, 90]. According to some authors and our own experience, biliary decompression of duct-to-duct anastomosis may be more indicated in partial-liver graft transplantation when it may reduce the risk of both cut surface and anastomotic biliary leaks [25, $32,43,45,63]$. However, this has not been confirmed in a prospective randomized study.

\section{Biliary Leaks}

Biliary leaks after OLT are seen in $0.3-22 \%$ of patients, and may be anastomotic and non-anastomotic in site, i.e. originating from the T-tube exit site or from the cut sur- 


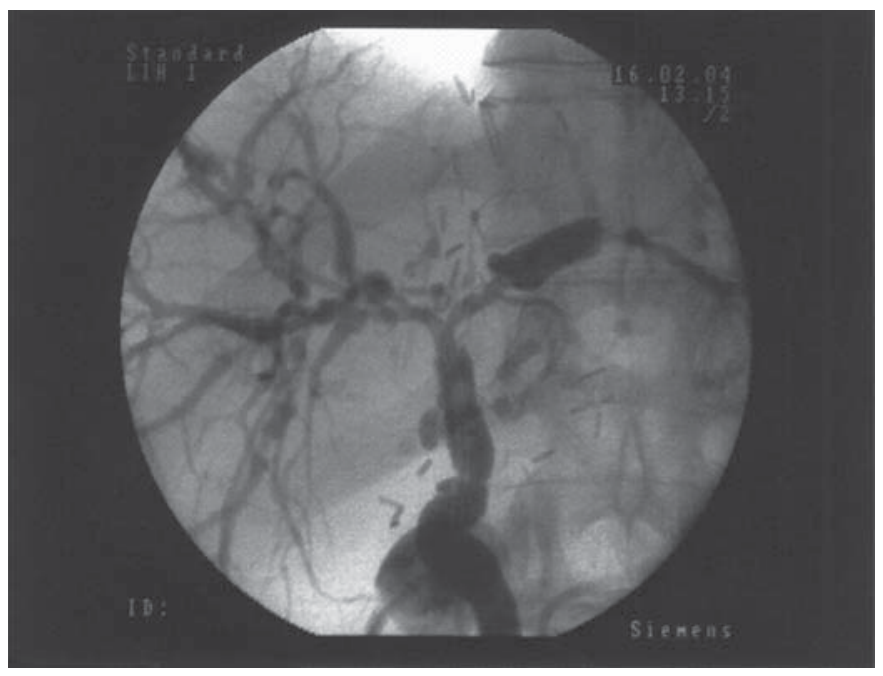

Fig. 1. Bile drain cholangiogram showing multiple hilar biliary strictures and dilatations in a patient with hepatic artery thrombosis 4 months after orthotopic liver transplantation.

face of the graft in case of partial liver graft transplantation $[5,6,8,9,107,108]$. As a general rule, the majority occur early in the postoperative period and mandate operative or endoscopic intervention to avoid sepsis [5]. Anastomotic leaks are mainly related to errors in surgical technique and/or ischemic necrosis at the end of the bile duct. They occur at a similar rate after duct-to-duct and bilioenteric anastomosis [7, 62, 109], and the incidence also appears to be equal in patients with duct-to-duct anastomosis with or without a T-tube $[9,89,90]$.

Anastomotic leaks frequently resolve on their own after a short course of unclamping of the T-tube, endoscopic sphincterotomy and stenting [109], or percutaneous transhepatic cholangiography-guided drainage [110], but may be a risk factor for subsequent development of an anastomotic stricture $[11,111,112]$. Larger leaks, particularly those associated with bilioenteric anastomosis, tend to be less amenable to non-operative treatment and immediate or early operative revision should be strongly considered [100, 108, 113, 114].

Biliary leaks following T-tube removal are managed by either an urgent relaparotomy and suture closure of the leak or non-operative endoscopic treatment first [5, $95,109,115]$. Endoscopic sphincterotomy and stenting or nasobiliary drainage, however, appear to emerge as the preferred treatment options in case of both leaks after $\mathrm{T}$ -

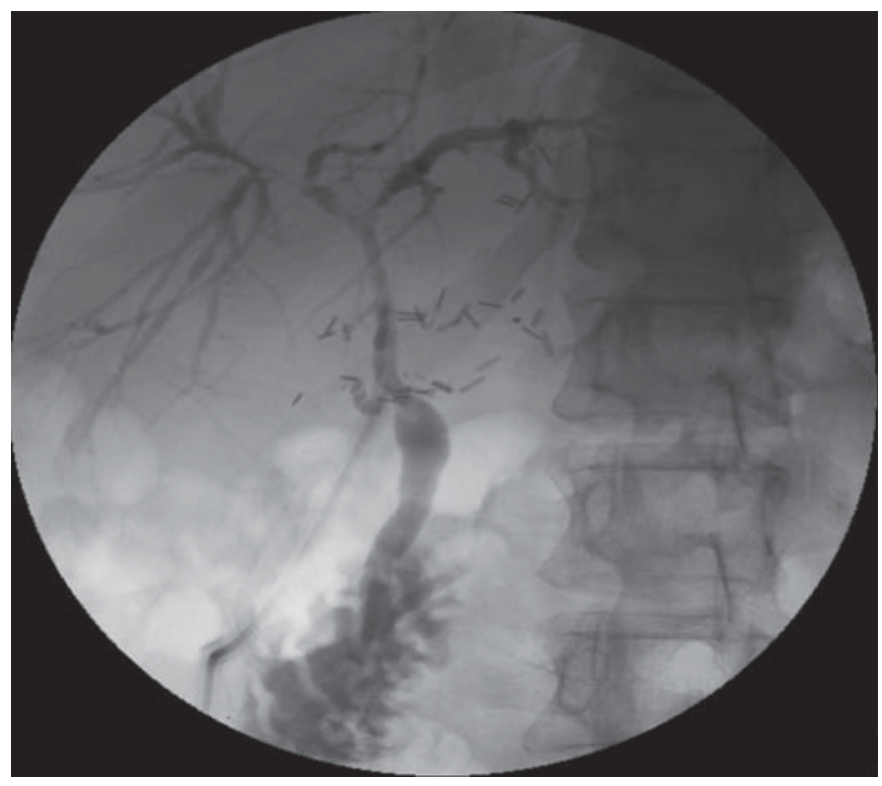

Fig. 2. Endoscopic cholangiogram showing ischemic-type biliary lesions 11 months following orthotopic liver transplantation.

tube removal and cut surface biliary leaks, restricting surgery to patients with frank peritonitis and/or large leaks [116-118]. Endoscopic placement of nasobiliary catheters may offer the advantage of access for cholangiography and easy removal [104]. In any case, associated intra-abdominal bile collection (biloma) should be treated by percutaneous ultrasound-guided or CT-guided drainage $[101,110]$.

\section{Biliary Strictures}

Biliary strictures complicate around $2-14 \%$ of OLT and are classified as anastomotic and non-anastomotic in site $[5-11,86,119,120]$. They may be due to technical causes, ischemia of the biliary tree due to hepatic artery thrombosis or stenosis (fig. 1), or fall into the category of ischemic-type biliary lesions (fig. 2) [54-61, 66]. Anastomotic strictures that appear early in the postoperative period are usually related to errors in the surgical technique, whereas later onset most likely indicates fibrotic healing due to ischemia at the end of the donor or recipient bile duct $[107,108,121]$. According to some series of wholeorgan OLT, they are reported to be more common after hepaticojejunostomy than after direct duct-to-duct anastomosis $[5,8,13]$, as well as following duct-to-duct anas- 

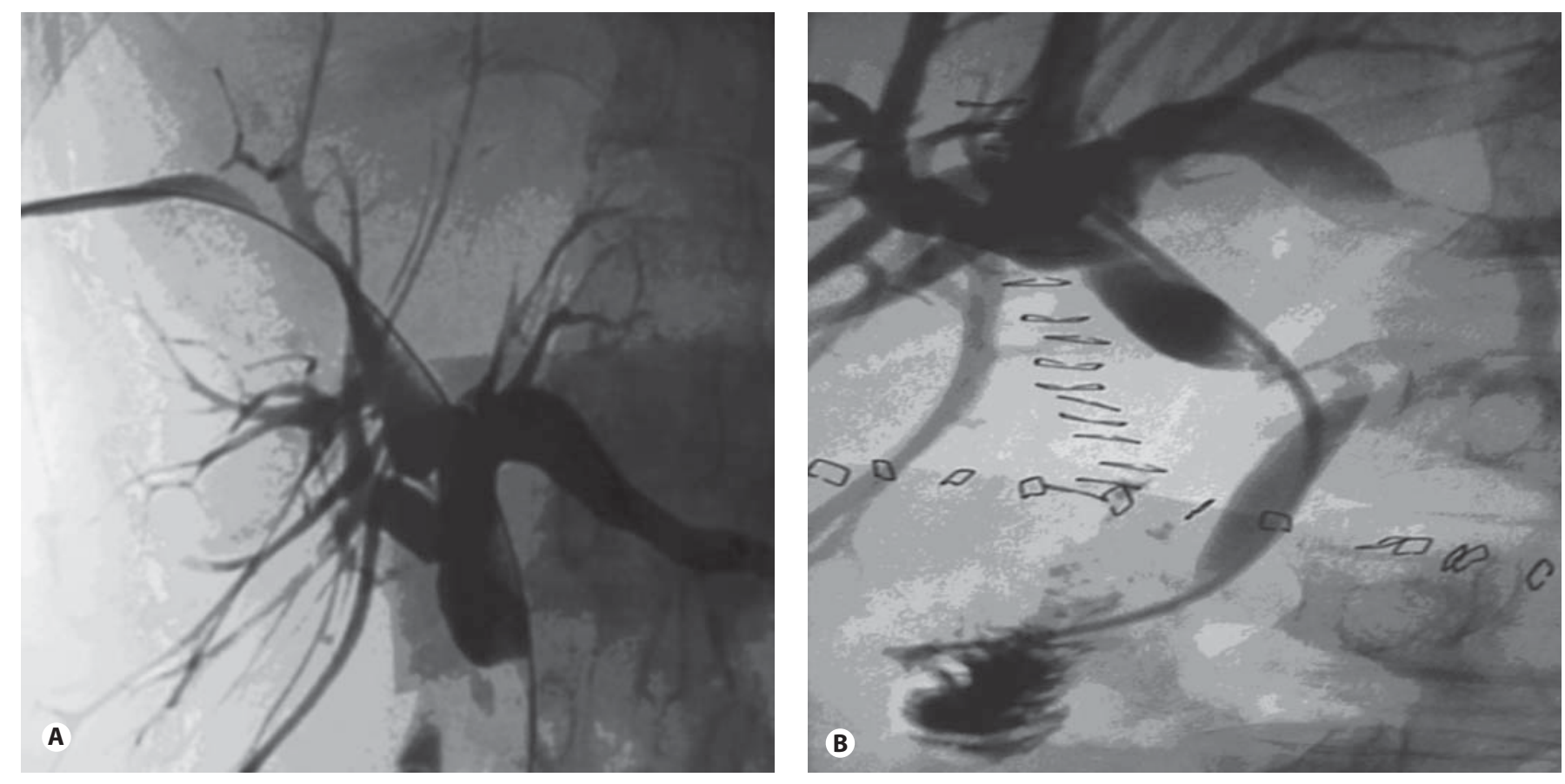

Fig. 3. Percutaneous cholangiogram showing a stricture at the duct-to-duct anastomosis 11 days after orthotopic liver transplantation (A) treated by percutaneous drainage (B) with endoscopic and percutaneous stenting (C).

tomosis in non-T-tube recipients, as compared to the anastomosis over a T-tube (table 5) [9, 86-90]. In right lobe living-donor transplants, the incidence of duct-toduct anastomotic strictures has been consistently higher, as compared to recipients of whole liver grafts $[24,25,32$, $34,44]$. This is considered to be related to the blood sup-

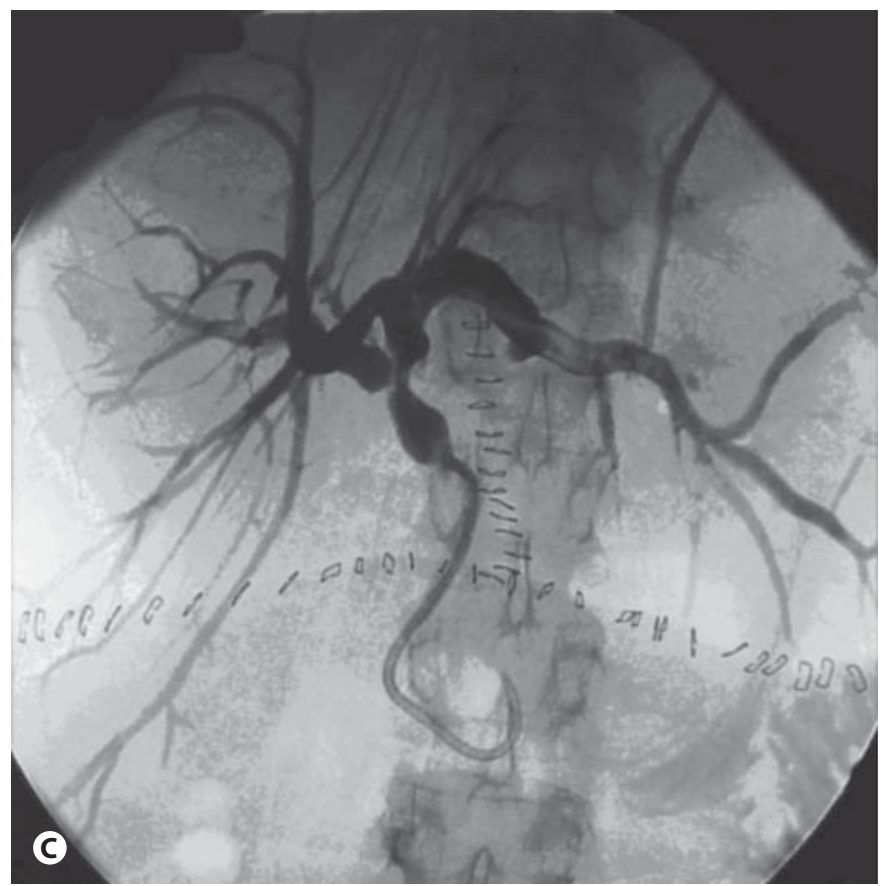

ply of the anastomosis and often the presence of multiple and small caliber donor ducts.

Uncomplicated anastomotic strictures usually respond well to either endoscopic or percutaneous dilatation and/or stenting (fig. 3) with a long-term success rate of more than $50-70 \%[107,108,116,122-124]$. Surgical 


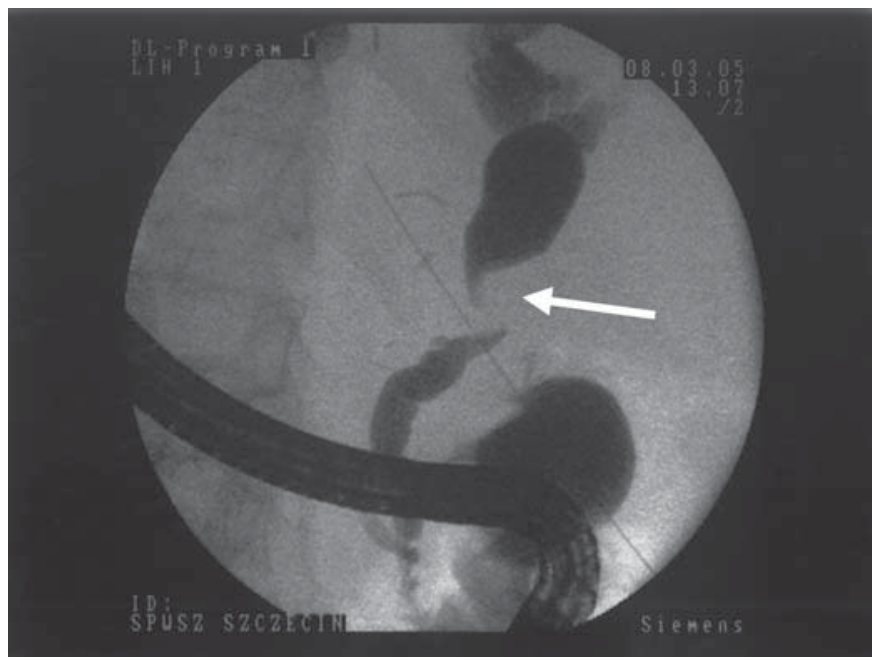

Fig. 4. Extrinsic compression on the distal common hepatic duct of the graft (arrow) by a cystic duct mucocele.

revision and biliary reconstruction with the formation of a hepaticojejunostomy is indicated when endoscopic or percutaneous treatment fails. Recurrent anastomotic strictures following biliary reconstruction develop in around $20 \%$ of patients and can still be effectively treated by balloon dilatation and/or stenting [114, 121, 125, 126].

The majority of non-anastomotic biliary strictures in liver transplant recipients are due to arterial insufficiency (fig. 1) or ischemic-type biliary lesions (fig. 2) [5, 53, 66, 107]. The strictures resulting from hepatic artery thrombosis have a much worse prognosis and a nonsurgical interventional treatment should be considered. This may be a definitive solution but more often can bridge the patient to liver retransplantation $[62,107,127]$. Ischemic-type biliary lesions occur in $2-20 \%$ of patients, are localized proximal to the anastomotic site, and on cholangiogram are indistinguishable from strictures caused by hepatic artery thrombosis $[66,68,69]$. They usually manifest themselves 1-6 months after OLT with most patients showing destroyed intrahepatic as well as extrahepatic bile ducts, while a few develop only extrahepatic or intrahepatic lesions $[54,66,68-70]$. In patients with changes located primarily in the extrahepatic bile duct and the duct bifurcation, complex surgical reconstruction with resection of the bifurcation and Roux-en-Y hepaticojejunostomy can be a successful treatment [125]. Intrahepatic ischemic-type biliary lesions tend to be more diffuse and difficult to manage and may require repeat transplantation or a permanent indwelling percutaneous transhepatic cholangiography-guided drainage in up to $50 \%$ of cases $[66,68,125,127-129]$. As a result of biliary stasis, early formation of gallstones, sludge, and casts in the biliary tree with an increased risk of ascending cholangitis has been reported [77, 78, 125].

\section{Cystic Duct Mucocele}

A tension mucocele of the cystic duct can develop when the outflow end of the blind donor cystic duct remnant is incorporated into the suture line of a biliary anastomosis [130]. This creates the blind mucosa-lined sac which can later on become distended by accumulated mucus, leading to bile duct obstruction by extrinsic compression (fig. 4). Prevention of this complication includes either complete excision of the cystic duct remnant prior to the anastomosis or obligatory division of the common septum between the donor cystic and common hepatic ducts before incorporating the remnant into the anastomotic suture line. The therapy of choice is surgical excision of the cystic duct remnant and a bilioenteric reconstruction $[121,130]$.

\section{Sphincter of Oddi Dysfunction}

Sphincter of Oddi dysfunction, also termed ampullary dysfunction, occurs in 3-5\% of liver transplant recipients, and presents with cholestasis, dilatation of the distal bile duct, and cholangiography failing to show any anatomic cause for biliary obstruction $[5,7,131]$. It may be due to operative denervation of the sphincter of Oddi during recipient hepatectomy, leading to subsequent impairment of ampullary relaxation and increased intraductal biliary pressure [132]. The diagnosis may be confirmed clinically by decreasing cholestasis with T-tube unclamping, delayed drainage of contrast medium after cholangiography, and manometry [133]. Endoscopic sphincterotomy and/or biliary stenting is usually a successful treatment, but conversion to a hepaticojejunostomy may occasionally be required [5].

\section{Hemobilia}

Hemobilia after OLT affects approximately $0.03 \%$ of recipients after liver biopsy and $3-6 \%$ of patients submitted to percutaneous transhepatic cholangiography [62, 134]. It may also occur in case of a common hepatic artery 
pseudoaneurysm rupturing into the common bile duct or Roux limb [135, 136]. Clinical symptoms may include right upper quadrant pain, upper gastrointestinal bleeding and biliary obstruction, whereas signs of peritonitis may follow a rupture of arterial pseudoaneurysm [62, 107]. The treatment may require both selective embolization of the vessel (angiographic or percutaneous) and endoscopic or percutaneous biliary drainage and/or thrombus extraction $[137,138]$. The hepatic artery pseudoaneurysm is treated with surgical resection and revascularization $[62,139,140]$.

\section{Recurrent Primary Sclerosing Cholangitis}

Primary sclerosing cholangitis recurs after OLT in 5$20 \%$ of patients $[60,141-145]$ and the risk of recurrence appears to be increased in males and recipients having an intact colon before transplantation [141]. The recurrence has been difficult to prove as it can be indistinguishable from ischemic-type biliary lesions due to other causes [144]. The diagnosis is based on the confirmed diagnosis of primary sclerosing cholangitis before transplantation and either cholangiographic or histologic evidence, showing fibrous cholangitis and/or fibro-obliterative lesions, ductopenia, biliary fibrosis, or biliary cirrhosis. Cholangiographic findings are non-anastomotic biliary strictures of the intrahepatic and/or extrahepatic biliary tree with beading and irregularity occurring more than 90 days after transplantation [60]. Differential diagnosis includes hepatic artery thrombosis or stenosis and ischemic-type biliary lesions of other etiology. As of today, patient and graft survival does not appear to be negatively affected by the recurrent primary sclerosing cholangitis in the intermediate term of follow-up [146].

Biliary reconstruction during OLT for primary sclerosing cholangitis has been routinely performed using a Roux loop with the aim to reduce the risk of disease recurrence within the distal native bile duct [29]. Some groups, however, perform duct-to-duct anastomosis in these patients if there is no evidence of distal duct stricturing or inflammation, and comparable results (ductto-duct versus hepaticojejunostomy) in terms of the rates of biliary complications and patient and graft survival have been reported [147-149]. This is in contrast with the recently published UK transplant data of more than 360 patients transplanted for primary sclerosing cholangitis between 1994 and 2003 in seven UK transplant centers [150]. An increased incidence of biliary strictures and reduced graft and patient survival were observed in patients with duct-to-duct anastomosis, as compared to those undergoing hepaticojejunostomy reconstruction.

\section{Conclusions}

Biliary complications after OLT may be related to many factors including hepatic artery thrombosis or stenosis, ischemia-reperfusion injury, immunologic injury, infections, and technical reasons. The latter include imperfect anastomosis, T-tube-related complications and increasing use of partial liver grafts in living-donor and split-liver transplantation. Meticulous surgical technique of both performing the arterial and biliary anastomosis, as well as when dissecting the bile ducts during donor and recipient hepatectomy, is paramount. In view of the high rates of T-tube-related biliary complications, many groups have abandoned the use of the T-tube at wholeorgan OLT, which was shown to be safe, efficacious, and cost-effective, as compared to biliary reconstruction over a T-tube $[84,85,102,103]$. This conforms with the results from two prospective, randomized trials showing no advantage of biliary drainage at whole-organ OLT $[86,88]$. The non-operative management of biliary complications following OLT has become standard practice with interventional radiology and endoscopic techniques emerging as the preferred treatment option, obviating the need for surgery in a selected majority of patients.

References $\quad 1$ Calne RY: A new technique for biliary drainage in orthotopic liver transplantation utilizing the gallbladder as a pedicle graft conduit between the donor and recipient common bile ducts. Ann Surg 1976;184: 605-609.

-2 Starzl TE, Putnam CW, Hansbrough JF, Porter KA, Reid HA: Biliary complications after liver transplantation with special reference to the biliary cast syndrome and techniques of secondary duct repair. Surgery 1977;81: 212-221.

3 Williams R, Smith M, Shilkin KB, Herbertson B, Joysey V, Calne RY: Liver transplantation in man: the frequency of rejection, biliary tract complications and recurrence of malignancy based on an analysis of 26 cases. Gastroenterology 1973;64:10261048.

4 Calne RY, McMaster P, Portmann B, Wall WJ, Williams R: Observations on preservation, bile drainage and rejection in 64 human orthotopic liver allografts. Ann Surg 1977; 186:282-290. 
5 Greif F, Bronsther OL, Van Thiel DH, Casavilla A, Iwatsuki S, Tzakis A, Todo S, Fung JJ, Starzl TE: The incidence, timing, and management of biliary complications after orthotopic liver transplantation. Ann Surg 1994;219:40-45.

6 Verran DJ, Asfar SK, Ghent CN, Grant DR, Wall WJ: Biliary reconstruction without Ttubes or stents in liver transplantation: report of 502 consecutive cases. Liver Transpl Surg 1997;3:365-373.

7 Neuhaus P, Blumhardt G, Bechstein WO, Steffen R, Platz KP, Keck H: Technique and results of biliary reconstruction using sideto-side choledochocholedochostomy in 300 orthotopic liver transplants. Ann Surg 1994; 219:426-434

8 O'Connor TP, Lewis WD, Jenkins RL: Biliary tract complications after liver transplantation. Ann Surg 1995;130:312-317.

-9 Rabkin JM, Orloff SL, Reed MH, Wheeler LJ, Corless CL, Benner KG, Flora KD, Rosen HR, Olyaei AJ: Biliary tract complications of side-to-side without T-tube versus end-toend with or without T-tube after choledochocholedochostomy in liver transplant recipients. Transplantation 1998;68:193-199.

-10 Davidson BR, Rai R, Kurzawinski TR, Selves L, Farouk M, Dooley JS, Burroughs AK, Rolles K: Prospective randomized trial of end-to-end versus side-to-side biliary reconstruction after orthotopic liver transplantation. Br J Surg 1999;86:447-452.

$\checkmark 11$ Welling TH, Heidt DG, Englesbe MJ, Magee JC, Sung RS, Campbell DA, Punch JD, Pelletier SJ: Biliary complications following liver transplantation in the model for end-stage liver disease era: effect of donor, recipient, and technical factors. Liver Transpl 2008; 14 : 73-80.

-12 Stratta RJ, Wood RP, Langnas AN, Hollins RR, Bruder KJ, Donovan JP, Burnett DA, Lieberman RP, Lund GB, Pillen TJ, Markin RS, Shaw BW: Diagnosis and treatment of biliary tract complications after orthotopic liver transplantation. Surgery 1989;106:675683.

13 Colonna JO 2nd, Shaked A, Gomes AS, Colquhoun SD, Jurim O, McDiarmid SV, Millis JM, Goldstein LI, Busuttil RW: Biliary strictures complicating liver transplantation. Ann Surg 1992;216:344-350.

- 14 Langnas AN, Marujo WC, Inagaki M, Stratta RJ, Wood RP, Shaw BW Jr: The results of reduced-size liver transplantation, including split livers, in patients with end-stage liver disease. Transplantation 1992;53:387-391.

15 De Ville de Goyet J: Split liver transplantation in Europe - 1988 to 1993 . Transplantation 1995;59:1371-1376.

-16 Noujaim HM, Gunson B, Mayer DA, Mirza DF, Candinas D, Buckels JA, McMaster P, de Ville de Goyet J: Worth continuing doing ex situ liver graft splitting? A single-center analysis. Am J Transplant 2003;3:318-323.
7 Reichert PR, Renz JF, Rosenthal P, Bacchetti P, Lim RC, Roberts JP, Ascher NL, Emond JC: Biliary complications of reduced-organ liver transplantation. Liver Transpl Surg 1998;4:343-349.

18 Renz JF, Yersiz H, Farmer DG, Hisatake GM, Ghobrial RM, Busuttil RW: Changing faces of liver transplantation: partial-liver grafts for adults. J Hepatobil Pancreat Surg 2003; 10:31-44.

19 Broelsch CE, Emond JC, Whitington PF, Thistlethwaite JR, Baker AL, Lichtor JL: Application of reduced size liver transplantation as split grafts, auxiliary orthotopic grafts and living related segmental transplants. Ann Surg 1990;212:368-375.

20 Kalayoglu M, D’Alessandro AM, Knechtle SJ, Hoffmann RM, Pirsch JD, Judd RH, Armbrust M, Spaith E, Pilli G, Young CJ, Geffner SR, Odorico JS, Sollinger HW, Belzer FO: Preliminary experience with split liver transplantation. J Am Coll Surg 1996;182:381387.

21 Bak T, Wachs M, Trotter J, Everson G, Trouillot T, Kugelmas M, Steinberg T, Kam I: Adult-to-adult living donor liver transplantation using right lobe grafts: Results and lessons learnt from a single-center experience. Liver Transpl 2001;7:680-686.

22 Testa G, Malago M, Valentin-Gamazo C, Lindell G, Broelsch CE: Biliary anastomosis in living related liver transplantation using the right liver lobe: Techniques and complications. Liver Transpl 2000;6:710-714.

23 Marcos A, Ham JM, Fisher RA, Olzinski AT, Posner MP: Single-center analysis of the first 40 adult-to-adult living donor liver transplants using the right lobe. Liver Transpl 2000;6:296-301.

24 Sampietro R, Goffette P, Danse E, De Reyck C, Roggen F, Ciccarelli O, Mathys J, Reding R, De Ville de Goyet J, Lerut J: Extension of the adult hepatic allograft pool using split liver transplantation. Acta Gastroenterol Belg 2005;68:369-375.

25 Yazumi S, Yoshimoto T, Hisatsune $H$, Hasegawa K, Kiola M, Tada S, Uenoyama Y, Yamauchi J, Shio S, Kasahara M, Ogawa K, Egawa H, Tanaka K, Chiba T: Endoscopic treatment of biliary complications after right-lobe living-donor liver transplantation with duct-to-duct biliary anastomosis. J Hepatobiliary Pancreat Surg 2006;13:502510.

26 Ringe B, Oldhafer $\mathrm{K}$, Bunzendahl $\mathrm{H}$, Bechstein WO, Kotzerke J, Pichlmayr R: Analysis of biliary complications following orthotopic liver transplantation. Transplant Proc 1989;21:2472-2476.

-27 Anselmi M, Sherlock D, Buist L, Zundel N Badger I, McMaster P, Buckels JA: Gallbladder conduit vs end-to-end anastomosis of the common bile duct in orthotopic liver transplantation. Transplant Proc 1990;22:22952296.
28 Halff G, Todo S, Hall R, Starzl TE: Late complications with gallbladder conduit biliary reconstruction after liver transplantation. Transplantation 1989;48:537-539.

29 Hiatt JR, Quinones-Baldrich WJ, Ramming KP: Operations upon the biliary tract during transplantation of the liver. Surg Gynecol Obstet 1987;165:89-93

30 Vallera RA, Cotton PB, Clavien PA: Biliary reconstruction for liver transplantation and management of biliary complications: overview and survey of current practices in the United States. Liver Transpl Surg 1995;1: 143-152.

31 Northover JMA, Terblanche J: A new look at the arterial supply of the bile duct in man and its surgical implications. Br J Surg 1979;66: 379-384

32 Stapleton GN, Hickman R, Terblanche J: Blood supply of the right and left hepatic ducts. Br J Surg 1998;85:202-207.

33 Azoulay D, Marin-Hargreaves G, Castaing D, Rene A, Bismuth H: Duct-to-duct biliary anastomosis in living related liver transplantation. Arch Surg 2001;136:1197-1200.

-34 Shokouh-Amiri MH, Grewal HP, Vera SR, Stratta RJ, Bagous W, Gaber AO: Duct-toduct biliary reconstruction in right lobe adult live donor liver transplantation. Ann Coll Surg 2001;192:798-803.

-35 Sugawara Y, Makuuchi M, Sano K, Ohkubo T, Kaneko J, Takayama T: Duct-to-duct biliary reconstruction in living-related liver transplantation. Transplantation 2002;73: 1348-1350.

>36 Settmacher Y, Steinmuller TH, Schmidt SC, Heise M, Pascher A, Theruvath T, Hintze R, Neuhaus P: Technique of bile duct reconstruction and management of biliary complications in right lobe living donor liver transplantation. Clin Transplant 2003;17: 37-42.

37 Fan S-T, Lo C-M, Liu C-L, Tso WK, Wong J: Biliary reconstruction and complications of right lobe live donor liver transplantation. Ann Surg 2002;236:676-683.

-38 Shah SA, Grant DR, McGilvray ID, Greig PD, Selzner M, Lilly LB, Girgrah N, Levy GA, Cattral MS: Biliary strictures in 130 consecutive right lobe living donor liver transplant recipients: results of a western center. Am J Transplant 2007;1:161-167.

39 Rogiers X, Malago M, Gawad K, Jauch KW, Olausson M, Knoefel WT, Gundlach M, Bassas A, Fisher L, Sterneck M, Burdelski M, Broelsch CE: In situ splitting of cadaveric livers. The ultimate expansion of a limited donor pool. Ann Surg 1996;224:331-341.

$\checkmark 40$ Azoulay D, Astarcioglu I, Bismuth H, Castaing D, Majno P, Adam R, Johann M: Splitliver transplantation. The Paul Brousse Policy. Ann Surg 1996;224:737-738.

41 Rela M, Vougas V, Muiesan P, Vilca-Melendez H, Smyrniotis V, Gibbs P, Karani J, Williams R, Heaton N: Split liver transplantation: King's College Hospital experience. Ann Surg 1998;227:282-288. 
-42 Yersiz H, Renz JF, Farmer DG, Hisatake GM, McDiarmid SV, Busuttil RW: One hundred in situ split-liver transplantations. A single center experience. Ann Surg 2003;238:496507.

43 Renz JF, Emond JC, Yersiz H, Ascher NL, Busuttil RW: Split-liver transplantation in the United States. Outcome of a national survey. Ann Surg 2004;239:172-181.

-44 Spada M, Cescon M, Aluffi A, Zambelli M, Guizzetti M, Lucianetti A, Pinelli D, Strazzabosco M, Gridelli B, Colledan M: Use of extended right grafts from in situ split livers in adult liver transplantation: a comparison with whole-liver transplants. Transplant Proc 2005;37:1164-1166.

45 Wojcicki M, Silva MA, Jethwa P, Gunson B, Bramhall SR, Mayer D, Buckels JA, Mirza DF: Biliary complications following adult right lobe ex vivo split liver transplantation. Liver Transpl 2006;12:839-844.

-46 Gondolesi GE, Varotti G, Florman SS, Munoz L, Fishbein TM, Emre SH, Schwartz ME, Miller C: Biliary complications in 96 consecutive right lobe living donor transplant recipients. Transplantation 2004;77:18421848

47 Ishiko T, Egawa H, Kasahara M, Nakamura T, Oike F, Kaihara S, Kiuchi T, Uemoto S, Inomata Y, Tanaka K: Duct-to-duct biliary reconstruction in living donor liver transplantation utilizing right lobe graft. Ann Surg 2002;236:235-240.

48 Liu CL, Lo CM, Chan SC, Fan ST: Safety of duct-to-duct biliary reconstruction in rightlobe live-donor liver transplantation without biliary drainage. Transplantation 2004;77: 726-732.

-49 Deshpande RR, Bowles MJ, Vilca-Melendez $\mathrm{H}$, Srinivasan P, Girlanda R, Dhawan A, Mieli-Vergani G, Muiesan P, Heaton ND, Rela M: Results of split liver transplantation in children. Ann Surg 2002;236:248-253.

50 Miller CM, Gondolesi GE, Florman S, Matsumoto C, Munoz L, Yoshizumi T, Artis T, Fishbein TM, Sheiner PA, Kim-Schluger L, Schiano T, Shneider BL, Emre S, Schwartz ME: One hundred nine living donor liver transplants in adults and children: a single-center experience. Ann Surg 2001;234:301-311.

-51 Soejima Y, Shimada M, Suehiro T, Kishikawa K, Minagawa R, Hiroshige S, Ninomiya M, Shiotani S, Harada N, Sugimachi K: Feasibility of duct-to-duct biliary reconstruction in left-lobe adult-living-donor liver transplantation. Transplantation 2003;75:557-559.

-52 Kawachi S, Shimazu M, Wakabayashi G, Hoshino K, Tanabe M, Yoshida M, Morikawa Y, Kitajima M: Biliary complications in adult living donor liver transplantation with duct-to-duct hepaticocholedochostomy or Roux-en-Y hepaticojejunostomy biliary reconstruction. Surgery 2002;132:48-56.

- 53 Zajko AB, Campbell WL, Logsdon GA, Bron KM, Tzakis A, Esquivel CO, Starzl TE: Cholangiographic findings in hepatic artery occlusion after liver transplantation. AJR Am J Roentgenol 1987;149:485-489.
54 Sanchez-Urdazpal L, Gores GJ, Ward EM, Maus TP, Wahlstrom HE, Moore SB, Wiesner RH, Krom RA: Ischemic-type biliary complications after orthotopic liver transplantation. Hepatology 1992;16:49-53.

55 Scotte M, Dousset B, Calmus Y, Conti F, Houssin D, Chapuis Y: The influence of cold ischemia time on biliary complications following liver transplantation. J Hepatol 1994; 21:340-346.

56 Demetris AJ, Qian SG, Sun H, Fung JJ: Liver allograft rejection: An overview of morphological findings. Am J Surg Pathol 1990; 14(suppl 1):49-63.

57 O'Grady JG, Alexander GJ, Sutherland S, Donaldson PT, Harvey F, Portmann B, Calne RY, Williams R: Cytomegalovirus infection and donor/recipient HLA-antigens: interdependent co-factors in pathogenesis of vanishing bile duct syndrome after liver transplantation. Lancet 1988;2:302-305

58 Lautenschlager I, Hockerstedt K, Jalanko H Loginov R, Salmela K, Taskinen E, Ahonen J: Persistent cytomegalovirus in liver allografts with chronic rejection. Hepatology 1997;25:190-194.

59 Evans PC, Smith S, Hirschfield G, Rigopoulou E, Wreghitt TG, Wight DG, Taylor CJ, Alexander GJ: Recipient HLA-DR3, tumour necrosis factor-[alpha] promoter allele-2 (tumour necrosis factor-2) and cytomegalovirus infection are inter-related risk factors for chronic rejection in liver grafts. J Hepatol 2001;34:711-715.

60 Graziadei IW, Wiesner RH, Batts KP, Marotta PJ, LaRusso NF, Porayko MK, Hay JE, Gores GJ, Charlton MR, Ludwig J, Poterucha JJ, Steers JL, Krom RAF: Recurrence of primary sclerosing cholangitis following liver transplantation. Hepatology 1999;29:10501056.

61 Sanchez-Urdazpal L, Batts KP, Gores GJ, Moore SB, Sterioff S, Wiesner RH, Krom RAF: Increased bile duct complications in liver transplantation across the ABO barrier. Ann Surg 1993;218:152-158.

62 Maguire D, Rela M, Heaton ND: Biliary complications after orthotopic liver transplantation. Transplant Rev 2002;16:220 240 .

63 Goss JA, Yersiz H, Shackleton CR, Seu P, Smith CV, Markowitz JS, Farmer DG, Ghobrial RM, Markmann JF, Amaout WS, Imagawa DK, Colquhoun SD, Fraiman $\mathrm{MH}$, McDiarmid SV, Busuttil RW: In situ splitting of the cadaveric liver for transplantation. Transplantation 1997;64:871-877.

64 Reyes J, Gerber D, Mazariegos GV, Casavilla A, Sindhi R, Bueno J, Madariaga J, Fung JJ: Split-liver transplantation: a comparison of ex vivo and in situ techniques. J Pediatr Surg 2000;35:283-289.

65 Corno V, Colledan M, Dezza MC, Guizzetti M, Lucianetti A, Maldini G, Pinelli D, Giovanelli M, Zambelli M, Torre G, Strazzabosco M: Extended right split liver graft for primary transplantation in children and adults. Transpl Int 2006;19:492-499.
66 Sanchez-Urdazpal L, Gores GJ, Ward EM, Maus TP, Buckel EG, Steers JL, Wiesner RH, Krom RA: Diagnostic features and clinical outcome of ischemic-type biliary complications after liver transplantation. Hepatology 1993; 17:605-609.

67 Theilman L, Kuppers B, Kadmon M, Roeren T, Notheisen H, Stiehl A, Otto G: Biliary tract strictures after orthotopic liver transplantation: diagnosis and management. Endoscopy 1994;26:517-522.

68 Fisher A, Miller CM: Ischemic-type biliary strictures in liver allografts: the Achilles heel revisited? Hepatology 1995;21:589-591.

69 Sankary HN, McChesney L, Hart M, Foster P, Williams J: Identification of donor and recipient risk factors associated with nonanastomotic biliary strictures in human hepatic allografts. Transplant Proc 1993;25:1964-1967.

70 Sankary HN, McChesney L, Frye E, Cohn S, Foster P, Williams J: A simple modification in operative technique can reduce the incidence of nonanastomotic biliary strictures after liver transplantation. Hepatology 1995; 21:63-69.

71 Suarez F, Otero A, Solla M, Arnal F, Lorenzo MJ, Marini M, Vazquez-Iglesias JL, Gomez M: Biliary complications after liver transplantation from Maastricht category-2 nonheart-beating donors. Transplantation 2008; 85:9-14.

72 Moench C, Moench K, Lohse AW, Thies J, Otto G: Prevention of ischemic-type biliary lesions by arterial back-table pressure perfusion. Liver Transpl 2003;9:285-289.

73 Pirenne J, Van Gelder F, Coosemans W, Aerts R, Gunson B, Koshiba T, Fourneau I, Mirza D, Van Steenbergen W, Fevery J, Nevens F, McMaster P: Type of donor aortic preservation solution and not cold ischemia time is a major determinant of biliary strictures after liver transplantation. Liver Transpl 2001;7:540-545.

74 Moench C, Otto G: Ischemic type biliary lesions in histidine-tryptophan-ketoglutarate (HTK) preserved liver grafts. Int J Artif Organs 2006;29:329-334.

75 Starzl TE, Putnam CW, Hansbrough JF, Porter KA, Reid HAS, Path MRC: Biliary complications after liver transplantation: with special reference to the biliary cast syndrome and techniques of secondary duct repair. Surgery 1977;81:212-221.

76 McMaster P, Herbertson BM, Cusick C, Calne RY, Syrakos T, Mami A: The development of biliary 'sludge' following liver transplantation. Transplant Proc 1979;11:262-266.

77 Barton P, Maier A, Steininger R, Muhlbacher F, Lechner G: Biliary sludge after liver transplantation: 1. Imaging findings and efficacy of various imaging procedures. AJR Am J Roentgenol 1995;164:859-864

78 Barton P, Steininger R, Maier A, Muhlbacher F, Lechner G: Biliary sludge after liver transplantation: 2 . Treatment with interventional techniques versus surgery and/or oral chemolysis. AJR Am J Roentgenol 1995;164: 865-870. 
-79 Fleischmann D: Multiple detector-row CT angiography of the renal and mesenteric vessels. Eur J Radiol 2003;45(suppl 1):S79-S87.

>80 Sadick M, Diehl SJ, Lehmann KJ, Gaa J, Mockel R, Georgi M: Evaluation of breathhold contrast-enhanced 3D magnetic resonance angiography technique for imaging visceral abdominal arteries and veins. Invest Radiol 2000;5:111-117.

-81 Gomes AS: Diagnosis and radiological treatment of biliary complications of liver transplantation. Semin Interv Radiol 1992;9:283299.

-82 Lopez RR, Benner KG, Ivancev K, Keeffe EB, Deveney CW, Pinson CW: Management of biliary complications after liver transplantation. Am J Surg 1992;163:519-524.

-83 Zemel G, Zajko AB, Skolnick ML, Bron KM, Campbell WL: The role of sonography and transhepatic cholangiography in the diagnosis of biliary complications after liver transplantation. AJR Am J Roentgenol 1988;151: 943-946.

-84 Boraschi P, Braccini G, Gigoni R, Sartoni G, Neri E, Filipponi F, Mosca F, Bartolozzi C: Detection of biliary complications after orthotopic liver transplantation with MR cholangiography. Magn Reson Imaging 2001;19: 1097-1105.

-85 Thune A, Friman S, Persson H, Berglund B, Nilsson B, Svanvik J: Raised pressure in the bile ducts after orthotopic liver transplantation. Transpl Int 1994;7:243-246.

-86 Rouch DA, Emond JC, Thistlethwaite JR, Mayes JT, Broelsch CE: Choledocholedocostomy without a $\mathrm{T}$ tube or internal stent in transplantation of the liver. Surg Gynecol Obstet 1990;170:239-244.

87 Rolles K, Dawson K, Novell R, Hayter B, Davidson $\mathrm{B}$, Burroughs A: Biliary anastomosis after liver transplantation does not benefit from T tube splintage. Transplantation 1994; 57:402-404.

88 Vougas V, Rela M, Gane E, Muiesan P, Vilca Melendez H, Williams R, Heaton ND: A prospective randomised trial of bile duct reconstruction at liver transplantation: T tube or not T tube? Transpl Int 1996;9:392-395.

-89 Nuno J, Vicente E, Turrion VS, Pereira F, Ardaiz J, Cuervas V, Barcena R, Garcia M, San Roman AL, Candela A, Honrubia A, Moreno A: Biliary tract reconstruction after liver transplantation: with or without $\mathrm{T}$ tube? Transplant Proc 1997;29:564-565.

-90 Scatton O, Meunier B, Cherqui D, Boillot O, Sauvanet A, Boudjema K, Launois B, Fagniez PL, Belghiti J, Wolff P, Houssin D, Soubrane O: Randomized trial of choledochocholedochostomy with or without a T tube in orthotopic liver transplantation. Ann Surg 2001; 223:432-437.

91 Kusano T, Randall HB, Roberts JP, Ascher NL: The use of stents for duct-to-duct anastomoses of biliary reconstruction in orthotopic liver transplantation. Hepatogastroenterology 2005;52:695-699.
-92 Ben Ari Z, Neville L, Davidson B, Rolles K, Burroughs AK: Infection rates with or without T-tube splintage of common bile duct anastomosis in liver transplantation. Transpl Int 1998;11:123-126.

$\checkmark 93$ Randall HB, Wachs ME, Somberg KA, Lake JR, Emond JC, Ascher NL, Roberts JP: The use of the $\mathrm{T}$ tube after orthotopic liver transplantation. Transplantation 1996;61: 258-261.

-94 Rossi G, Lucianetti A, Gridelli B, Colledan M, Caccamo L, Albani AP, Galmarini M, Fassati LR, Galmarini D: Biliary tract complications in 224 orthotopic liver transplantations. Transplant Proc 1994;26: 3626-3628

95 Sheng R, Sammon JK, Zajko AB, Campbell WL: Bile leak after hepatic transplantation: cholangiographic features, prevalence, and clinical outcome. Radiology 1994;192:413416.

-96 Grande L, Perez-Castilla A, Matus D, Rodriguez-Montalvo C, Rimola A, Navasa M, Garcia-Valdecasas JC, Visa J: Routine use of the T-tube in the biliary reconstruction of liver transplantation: Is it worthwhile? Transplant Proc 1999;31:2396-2397.

$\checkmark 97$ Shuhart MC, Kowdley KV, McVicar JP, Rohrmann CA, McDonald MF, Wadland DW, Emerson SS, Carithers RR Jr, Kimmey MB: Predictors of bile leak after T-tube removal in orthotopic liver transplant recipients. Liver Transpl Surg 1998;4:62-70.

$\checkmark 98$ Urbani L, Campatelli A, Romagnoli J, Catalano G, Sartoni G, Costa A, Vignali C, Mosca F, Filipponi F: T-tube removal after liver transplantation: a new technique that reduces biliary complications. Transplantation 2002;74:410-413.

$\checkmark 99$ Goodwin SC, Bittner CA, Patel MC, Noronha MA, Chao K, Sayre JW: Technique for reduction of bile peritonitis after T-tube removal in liver transplant patients. J Vasc Interv Radiol 1998;9:986-990.

100 Abouljoud MS, Escobar F, Douzdjian V, Moonka D, Shick L, Brown KA: Successful strategy for reducing biliary complications after liver transplantation. Transplant Proc 2001;33:2714-2715.

101 Klein AS, Savader S, Burdick JF, Fair J, Mitchell M, Colombani P, Perler B, Osterman F, Williams GM: Reduction of morbidity and mortality from biliary complications afterliver transplantation. Hepatology 1991;14:818-823.

102 Sawyer RG, Punch JD: Incidence and management of biliary complications after 291 liver transplants following the introduction of transcystic stenting. Transplantation 1998;66:1201-1207.

103 Barkun JS, Tzimas GN, Cantarovich M, Metrakos PP, Deschenes M, Alpert E, Paraskevas S, Tchervenkov JI: Do biliary endoprostheses decrease biliary complications after liver transplantation? Transplant Proc 2003;35:2435-2437.
104 Saab S, Martin P, Soliman GY, Machicado GA, Roth BE, Kunder G, Han SH, Farmer DG, Ghobrial RM, Busuttil RW, Bedford RA: Endoscopic management of biliary leaks after T-tube removal in liver transplant recipients: nasobiliary drainage versus biliary stenting. Liver Transpl 2000;6: 627-632.

105 Shimoda M, Saab S, Morrisey M, Ghobrial RM, Farmer DG, Chen P, Han SH, Bedford RA, Goldstein LI, Martin P, Busuttil RW: A cost effectiveness analysis of biliary anastomosis with or without T-tube after orthotopic liver transplantation. Am J Transplant 2001;1:157-161.

106 Amador A, Charco R, Marti J, Navasa M, Rimola A, Calatayud D, Rodriguez-Laiz G, Ferrer J, Romero J, Ginesta C, Fondevila C, Fuster J, Hotter G, Garcia-Valdecasas JC: Clinical trial on the cost-effectiveness of Ttube use in an established deceased donor liver transplant program. Clin Transplant 2007;21:548-553.

107 Tung BY, Kimmey MB: Biliary complications of orthotopic liver transplantation. Dig Dis 1999;17:133-144.

108 Jagannath S, Kalloo AN: Biliary complications after liver transplantation. Curr Treat Options Gastroenterol 2002;5:101-112.

109 Osorio RW, Friese CE, Stock PG, Lake JR, Laberge JM, Gordon RL, Ring EJ, Ascher NL, Roberts JP: Nonoperative management of biliary leaks after orthotopic liver transplantation. Transplantation 1993;55:10741077.

110 Johnston TD, Gates R, Reddy KS, Nickl NJ, Ranjan D: Nonoperative management of bile leaks following liver transplantation. Clin Transplant 2000;14:365-369.

111 Bourgeois N, Deviere J, Yeaton P, Bourgeois F, Adler M, Van De Stadt J, Gelin M, Cremer M: Diagnostic and therapeutic endoscopic retrograde cholangiography after liver transplantation. Gastrointest Endosc 1995; 42:527-534.

112 Verdonk RC, Buis CI, Porte RJ, Van der Jagt EJ, Limburg AJ, Van den Berg AP, Slooff MJ, Peeters PM, de Jong KP, Kleibeuker JH, Haagsma EB: Anastomotic biliary strictures after liver transplantation: causes and consequences. Liver Transpl 2006;12:726735.

113 Testa G, Malago M, Broelsch CE: Complications of biliary tract in liver transplantation. World J Surg 2001;25:1296-1299.

114 Davidson BR, Rai R, Nandy A, Doctor N, Burroughs A, Rolles K: Results of choledochojejunostomy in the treatment of biliary complications after liver transplantation in the era of nonsurgical therapies. Liver Transpl 2000;6:201-206.

115 Sherman S, Jamidar P, Shaked A, Kendall BJ, Goldstein LI, Busuttil RW: Biliary tract complications after orthotopic liver transplantation. Endoscopic approach to diagnosis and therapy. Transplantation 1995; 60:467-470. 
116 Macfarlane B, Davidson B, Dooley JS, Dawson K, Osborne MJ, Rolles K, Burroughs AK: Endoscopic retrograde cholangiography in the diagnosis and endoscopic management of biliary complications after liver transplantation. Eur J Gastroenterol Hepatol 1996;8:1003-1006.

117 Thuluvath PJ, Atassi T, Lee J: An endoscopic approach to biliary complications following orthotopic liver transplantation. Liver Int 2003;23:156-162.

118 Pfau PR, Kochman ML, Lewis JD, Long WB, Lucey MR, Olthoff K, Shaked A, Ginsberg GG: Endoscopic management of postoperative biliary complications in orthotopic liver transplantation. Gastrointest Endosc 2000;52:55-63.

119 Lebeau G, Yanaga K, Marsh JW, Tzakis AG, Makowka L, Gordon RD, Todo S, Stieber AC, Iwatsuki S, Starzl TE: Analysis of surgical complications after 397 hepatic transplantations. Surg Gynecol Obstet 1990;170: 317-322.

120 Belli L, De Carlis L, Del Favero E, Rondinara G, Meroni A, Zani B, Rimoldi P, Cazzulani A, Brambilla G, Beati C: Biliary complications in orthotopic liver transplantation: experience with a modified technique of duct-to-duct reconstruction. Transpl Int 1991;4:161-165.

121 Porayko MK, Kondo M, Steers JL: Liver transplantation: late complications of the biliary tract and their management. Semin Liver Dis 1995;15:139-155.

-122 Rossi AF, Grosso C, Zanasi G, Gambitta P, Bini M, De Carlis L, Rondinara G, Arcidiacono R: Long-term efficacy of endoscopic stenting in patients with stricture of the biliary anastomosis after orthotopic liver transplantation. Endoscopy 1998;30:360366.

123 Mahajani RV, Cotler SJ, Uzor F: Efficacy of endoscopic management of anastomotic biliary strictures after liver transplantation. Endoscopy 2000;32:943-949.

-124 Schwartz DA, Pettersen BT, Poterucha JJ, Gostout CJ: Endoscopic therapy of anastomotic bile duct strictures occurring after liver transplantation. Gastrointest Endosc 2000;51:169-174.

125 Schlitt HJ, Meier PN, Nashan B, Oldhafer KJ, Boeker K, Flemming P, Raab R, Manns MP, Pichlmayr R: Reconstructive surgery for ischemic-type lesions at the bile duct bifurcation after liver transplantation. Ann Surg 1999;229:137-145

-126 Alazmi WM, FogelEL, Watkins JL, McHenry L, Tector JA, Fridell J, Mosler P, Sherman S, Lehman GA: Recurrence rate of anastomotic biliary strictures in patients who have had previous successful endoscopic therapy for anastomotic narrowing after orthotopic liver transplantation. Endoscopy $2006 ; 38: 571-574$.
127 Zajko AB, Campbell WL, Bron KM, Schade RR, Koneru B, Van Thiel DH: Diagnostic and interventional radiology in liver transplantation. Gastroenterol Clin North Am 1988;17:105-143.

128 Ward EM, Kiely MJ, Maus TP, Wiesner RH, Krom RA: Hilar biliary strictures after liver transplantation: cholangiography and percutaneous treatment. Radiology 1990; 177:259-263.

129 Campbell WL, Sheng R, Zajko AB, Abu-Elmagd K, Demetris AJ: Intrahepatic biliary strictures after liver transplantation. Radiology 1994;191:735-740.

130 Koneru B, Zajko AB, Sher L, Marsh JW, Tzakis AG, Iwatsuki S, Starzl TE: Obstructing mucocele of the cystic duct after transplantation of the liver. Surg Gynecol Obstet 1989;168:394-396

131 Douzdjian V, Abecassis MM, Johlin FC: Sphincter of Oddi dysfunction following liver transplantation. Screening by bedside manometry and definitive manometric evaluation. Dig Dis Sci 1994;39:253-256.

132 Clavien PA, Camargo CA Jr, Baillie L, Fitz JG: Sphincter of Oddi dysfunction after liver transplantation. Dig Dis Sci 1995;40:73-74.

133 Richards RD, Yeaton P, Shaffer HA Jr, Pambianco DJ, Pruett TL, Stevenson WC, Mittal RK, McCallum RW: Human sphincter of Oddi motility and cholecystokinin response following liver transplantation. Dig Dis Sci 1993;38:462-468.

- 134 Croutch KL, Gordon RL, Ring EJ, Kerlan RK Jr, La Berge JM, Roberts JP: Superselective arterial embolization in the liver transplant recipient: A safe treatment for hemobilia caused by percutaneous transhepatic biliary drainage. Liver Transpl Surg 1996;2: 118-123.

135 Merhav H, Zajko AB, Dodd GD, Pinna A: Percutaneous transhepatic embolization of an intrahepatic pseudoaneurysm following liver biopsy in a transplant patient. Transpl Int 1992;6:239-241.

136 Zajko AB, Chablani V, Bron KM, Jungreis C: Hemobilia complicating transhepatic catheter drainage in liver transplant recipients: management with selective embolization. Cardiovasc Intervent Radiol 1990;13: 285-288.

137 Manzarbeitia C, Jonsson J, Rustgi V, Oyloe VK, Olson L, Hefter L, Kankam C: Management of hemobilia after liver biopsy in liver transplant recipients. Transplantation 1993;56:1545-1547.

138 Pitre J, Dousset B, Massault PP, Soubrane O, Legmann P, Houssin D: Multiple intrahepatic stones caused by hemobilia in liver transplant recipients. Surgery 1997;121:352-354.
139 Riedmann B, Pernthaler H, Konigsrainer A, Nachbaur K, Vogel W, Margreiter R: Life threatening gastrointestinal bleeding after liver transplantation due to hepatic artery pseudoaneurysm perforating into the common bile duct. Transpl Int 1995;8:492495.

140 Lowell JA, Coopersmith CM, Shenoy S, Howard TK: Unusual presentations of nonmycotic hepatic artery pseudoaneurysms after liver transplantation. Liver Transpl Surg 1999;5:200-203.

141 Vera A, Moledina S, Gunson B, Hubscher S, Mirza D, Olliff S, Neuberger J: Risk factors for recurrence of primary sclerosing cholangitis of liver allograft. Lancet 2002;360: 1943-1944.

142 Narumi S, Roberts JP, Emond JC, Lake J, Asher NL: Liver transplantation for sclerosing cholangitis. Hepatology 1995;22:451457.

143 Goss JA, Shackleton CR, Farmer DG, Arnaout WS, Seu P, Markowitz JS, Martin P, Stribling RJ, Goldstein LI, Busuttil RW: Orthotopic liver transplantation for primary sclerosing cholangitis: A 12-year single center experience. Ann Surg 1997;225:472483.

144 Sheng R, Campbell WL, Zajko AB, Baron RL: Cholangiographic features of biliary strictures after liver transplantation for primary sclerosing cholangitis: evidence of recurrent disease. AJR Am J Roentgenol 1996;166:1109-1113.

145 Harrison RF, Davies MH, Neuberger JM, Hubscher SG: Fibrous and obliterative cholangitis in liver allografts: evidence of recurrent primary sclerosing cholangitis. Hepatology 1994;20:356-361.

146 Graziadei IW: Recurrence of primary sclerosing cholangitis after liver transplantation. Liver Transpl 2002;8:575-581.

147 Distante V, Farouk M, Kurzawinski TR, Ahmed SW, Burroughs AK, Davidson BR, Rolles K: Duct-to-duct biliary reconstruction following liver transplantation for primary sclerosing cholangitis. Transpl Int 1996;9:126-130.

148 Feith MP, Klompmaker IJ, Maring JK, Peeters PM, van den Berg AP, de Jong KP, Haagsma EB, Gouw AS, Slooff MJ: Biliary reconstruction during liver transplantation in patients with primary sclerosing cholangitis. Transplant Proc 1997;29:560561.

149 Heffron TG, Smallwood GA, Ramcharan T, Davis L, Connor K, Martinez F, Stieber AC: Duct-to-duct biliary anastomosis for patients with sclerosing cholangitis undergoing liver transplantation. Transplant Proc 2003;35:3006-3007.

150 Welsh FK, Wigmore SJ: Roux-en-Y choledochojejunostomy is the method of choice for biliary reconstruction in liver transplantation for primary sclerosing cholangitis. Transplantation 2004;77:602-604. 